\title{
Qualitative Approach on Investigating Failure Factors of Yemeni Mega Construction Projects
}

\author{
Yaser Gamil ${ }^{1, *}$, Ismail Abdul Rahman ${ }^{1}$, Sasitharan Nagapan ${ }^{1}$, and Nashwan Alemad ${ }^{1}$ \\ ${ }^{1}$ Faculty of Civil and Environmental Engineering, Universiti Tun Hussein Onn Malaysia, 86400, \\ Parit Raja, Johor, Malaysia
}

\begin{abstract}
Large construction projects in Yemen face many impediments and challenges to be completed successfully. This article presents an investigative cases study of three mega construction projects which are considered failed to achieve their assigned plans and objectives. An exploratory interview was implied in this study via telephone to three construction experts who involved directly in these mega projects at the managerial level. Semi-structured questions based on literature were designed as guide for the interview where the scope was mainly on causes of the mega projects failure. Outcomes from this study found that Yemen construction industry lacks of proper accrediting system to accredit construction stakeholders (contactors, consultant); improper planning for cost and time, lack of effective communication and coordination platforms and lack of advanced technology which are considered amongst the crucial challenges faced by industry. Hence, Yemeni construction industry is in dire needs of an effective platforms and system to administer project communication, information and coordination. Findings of this study can be useful for Yemeni construction community to understand causes of the failure and suggestions provided by experts are also very helpful in creating better quality works.
\end{abstract}

\section{Introduction}

Construction industry is complex, fragmented, diversified, schedule driven and involves many stakeholders, commonly faces chronic threats and challenges such as cost and time overruns, poor quality, waste generation etc [1-8]. This is no exception to Yemeni construction industry facing immeasurable challenges and problems where in many cases the projects failed completely to attain its designed plans and goals $[9,10]$. Among these challenges are poor management, poor planning, poor quality, poor monitoring construction materials cost fluctuation, cost and time overruns and failure of projects $[11,12]$. In early 1962 , Yemeni construction industry was governed by two bodies named municipal \& rural affairs authority and ministry of public works. Then in early 1976, the municipal and rural affairs were placed under the authority of ministry of public work to perform and undertake all the task under this body. However, in 1979 a new ministry of municipal affairs and housing was formed to differ from ministry of public work and forming two distinct entities

* Corresponding author: yaseruthm@yahoo.com 
where each of them has a set of functions and responsibilities. Unification of Yemen in 1990 has resulted to the formation of two separate ministries to govern construction industry which; the ministry of construction and development and the ministry of housing and urban planning. Again in 2003, there was a restructuring process of Yemen government which resulted to merge all the construction industry bodies under one discrete body named as ministry of public works and highways to undertake and administer all the construction industries projects [9]. Through the restructuring process of governmental ministries and agencies, the construction industry in Yemen has faced tremendous challenges for 26 years from the reunification of the country in 1990 until 2016 where the industry has defected and faced many development restraints and impediments $[10,11]$.

In Yemen, an accrediting body which allows construction stakeholders (contactors, consultant) to engage in construction work is the ministry of public works and highways. Unfortunately, this body still lack of proper sets of terms and also enforcements to the stakeholders. This caused to unqualified stakeholders participate in construction work which then results to negative sequences such as poor quality or even to project failure $[11,12]$. According to Sultan [11], there are 5 major barriers causing deterioration of Yemen construction industry which includes institutional and administrative weakness, red tape, corruption, followed by the lack of infrastructure and also the ineffective law [10]. Sultan [11] added that important factor causes regressive development and deficiencies of Yemen industry is lack of any approved national system of code and standards or specifications where constructions are often over-designed or inappropriate to local needs and priorities [13]. Many cases reported of demolition of structure due to erroneous design, questionable construction practices, or inappropriate material selection. Beside that many of the projects reported failed to achieve time and cost scheduled [11]. For that reason, Yemen government should focus on long-term strategies, plans and policies to an industry which is considered of the main contributor to the national economy to establish new approaches for changing the current state of Yemeni construction industry [13]. Therefore, this study explored qualitatively on the current challenges of Yemen construction projects and alongside on the failure causes of mega construction project. It is to acquire views of current construction industry in particulars mega construction projects which have failed to achieve their plans as a learning scenarios.

\section{Methodology of the study}

This qualitative study adopted an exploratory interview with construction experts who involved directly in the construction of mega project and have experience for more than 15 years in construction industry. The definition of expert in this study was adopted from a research findings by Fei \& Khan [5] which has specified the attributes and tangible criteria of an experts to be as follows (1) age should be older than 30 years (2) years of experience and involvement in construction industry should be more than 10 years (3) the expert should continuously work in a particular company for more than 10 years consequently Investigations on the failure causes of mega construction projects were conducted over telephone, Skype interviews and written answers due to difficulties to access Yemen under current situation. Each expert was given ample time to share their opinions based on his experiences in construction industry. In this exploratory interview, three construction experts were involved where they were selected based on their direct involvement in the mega projects. Therefore, they can be considered as representative of each individual mega project. Questions were designed with reference to previous literatures and findings. The main scope of questions is mainly on the general context of the projects and the causative failures of the projects further, experts were asked to highlight their opinions for preventive measures and future recommendation. Interviews transcriptions are produced in descriptive 
approach then filtered for relevancy to be in line with the contextual scope where each significant finding is presented in tabulation form and finally recommendations from experts were discussed for future improvements.

\section{Interview transcriptions}

This investigative study uncovered three mega projects in Yemen which are parliament complex, Sana'a international airport and Sana'a Sa'dah highway where the nominated projects were finally considered as failed. Exploration on these projects were conducted through interview sessions with three experts who are involved in the respective projects via telephone where questions were asked in a broad manner based on their knowledge and experiences working with these projects.

\subsection{Sana'a International Airport}

Construction of Sana'a international airport was financed by Arab Fund, while the construction was carried out by Chinese Company as the main contractor and an Arabic company as a consultant. A Dutch company was assigned to supervise special work of asphalt strengthening for the runways and supervising the work in the terminal building. Total cost for the project is 500 million USD while cost for consultant was $\$ 4$ million. For Asphalt work of runways and supervising the work in the terminal building, it cost of $\$$ $(2,269,724)$ dollars.

The expert who gave this feedback has 20 years of working experience in construction industry and holds a bachelor degree in civil engineering. In this project, he was appointed as project coordinator from the inception stage. The project started in 2006 and supposed to end by 2009 but is considered failed where only $40 \%$ of the total work project was accomplished during termination of contract. The main causes of project failure are poor planning, poor cost estimation, language difficulty and cultural diversity between construction practitioners, interference of government agencies to interrupt the work and lack of coordination among stakeholders considered very imperative to cause project failure. The expert gave additional factors lead to project failure which are lack of transparency between stakeholders and improper communication that led to the termination of contract. To him, lack of transparency leads to inaccessibility of project information by all stakeholders' hence causing misunderstanding and mistrust among project stakeholders. Also, improper communication caused by ineffective means and lack of technology resulted to ineffective flow of project communication during construction. Therefore, those combinations of factors finally lead to the suspension of contract with main contractors and resulted in the failure of the project.

\subsection{Parliament complex}

Respondent to provide information for parliament complex project is a former manager of this project. Has being working in Yemeni construction industry for more than 30 years and holds a bachelor degree in civil engineering. This project started early in 2006 and considered failed because only 50\% of the work has been accomplished until 2016. According to him, the contract amount for this project was paid in phases not in the form of lump sum. To him, it causes inaccurate planning and execution. Costing of the complex was based on four phases and the expert only managed to provide the cost allocated for phase one which was 24 million USD. According to the expert the project failed due to several reasons which include poor cost planning, bureaucracy, lack of transparency which 
later causes mistrust among construction parties, improper communication and coordination. Improper communication leads to unnecessary extra works likes redesign, rework and accident on site which also contribute to the failure of the project. According to him that lack of skill labors caused poor quality of work quality and incurred extra cost for more than $\$ 20,000$ to repair all the defective works. He pointed out that the failure of this project wasn't caused by a sole factor but through combinations of many factors integrated together and subsequently resulted in the suspension of the project. When asked share his opinions regarding the mitigation measures, he implied on providing training for the construction labors regarding the importance of safety measures before the commencement of the project and use of advanced technology to enhance the process of project communication and coordination.

\subsection{Sana'a -Sa'dah highway project}

Expert who shared information on this failed project is a former site engineer assigned to monitor and coordinate Sana'a Sa'dah highway project. He has more than 15 years of experience in construction and holds bachelor degree in civil engineering. This project was financed through the government's road maintenance fund and the main contractor was the ministry of public work while the subcontractors are local companies. It started in 2000 however only $50 \%$ of the work has been accomplished during the termination. Major cause of the project failure is due to employing non-qualified main contactor to take part of this project that led to unsuccessful completion. The main contractor then assigned different sub contactors for each individual road segments of the highway and causing too many contractors for the project. This is due to no standard guidelines and reference/terms to select and validate the legibility of contactor where it was done based on the knowledge of main contractor.

According to him, the progress of work process was regularly interrupted and suspended due to cash flow issue at the same time the subcontractors are not eligible to maintain the work during the interruption of cash flow therefore, since it is a road construction it is susceptible to environmental uncontrolled factors such as raining during season hence once rain happened the embanked road segments need to be re-embanked again due to the erosion caused by rain and that causes cost burden to the subcontractors and finally caused failure of the project.

\section{Results and discussion}

Reference to the interview transcriptions above, several pertinent points can be extracted and these points are as in Table 1. Table 1 shows summarization of significant results from these cases studies. Sixteen failure factors were extracted for the three mega projects. From these factors, it seems that few of the factors are appeared to be similar for the three projects which are poor planning, lack of accreditation of stakeholders, ineffective government bureaucracy and lack of advance technology to monitor work process. Besides highlighting failures of three mega projects, experts had suggested certain preventive measures and recommendations to enhance the process of construction in mega projects which would be norms and guidelines for future projects. It can be generalized that majority of the preventative measures should be adopted by government agencies. They are related to establishing accrediting and enforcement body to recognize construction stakeholders and also implementation usage of advanced technology in all construction industry facets. 
Table 1. Significant information of the three case studies

\begin{tabular}{|c|c|c|c|c|}
\hline & \multirow[b]{2}{*}{ Items } & \multicolumn{3}{|c|}{ Projects } \\
\hline & & Parliament complex & $\begin{array}{c}\text { Sana'a international } \\
\text { airport }\end{array}$ & $\begin{array}{c}\text { Sana'a-Sa'dah } \\
\text { highway }\end{array}$ \\
\hline \multirow{5}{*}{ 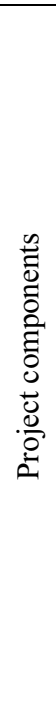 } & $\begin{array}{l}\text { Project } \\
\text { duration }\end{array}$ & $\begin{array}{c}\text { A year for each phase } \\
\text { (3 phases) }\end{array}$ & 3 years & 2 years \\
\hline & Total Cost & $\begin{array}{l}\text { For first phase of } \\
\text { project was } 24 \\
\text { million USD }\end{array}$ & 500million USD & 16 million USD \\
\hline & $\begin{array}{l}\text { Project } \\
\text { stakeholders }\end{array}$ & $\begin{array}{l}\text { - General military } \\
\text { division was main } \\
\text { contactor } \\
\text { - Client was the } \\
\text { government }\end{array}$ & $\begin{array}{l}\text { - Main contactor was } \\
\text { Chinese company } \\
\text { - Financing body was } \\
\text { Arab fund } \\
\text { - Consultant Yemeni } \\
\text { and Dutch (for asphalt } \\
\text { and runway } \\
\text { construction) }\end{array}$ & $\begin{array}{l}\text { - Main contractor was } \\
\text { ministry of public work } \\
\text { - Financing body was } \\
\text { road maintenance fund }\end{array}$ \\
\hline & $\begin{array}{l}\% \text { of } \\
\text { completion }\end{array}$ & $\begin{array}{l}\text { - About } 50 \% \text { of the } \\
\text { project work was } \\
\text { completed }\end{array}$ & $\begin{array}{l}-40 \% \text { of the work } \\
\text { project was } \\
\text { accomplished }\end{array}$ & - About $50 \%$ completed \\
\hline & $\begin{array}{l}\text { Estimated } \\
\text { loss }\end{array}$ & $\begin{array}{l}\text { - About } 50 \text { million } \\
\text { Riyal }\end{array}$ & $\begin{array}{l}\text { - Approximately more } \\
\text { than } 20 \% \text { of the total } \\
\text { cost }\end{array}$ & $\begin{array}{l}\text { - About } 50 \% \text { of the } \\
\text { total cost of the project }\end{array}$ \\
\hline & 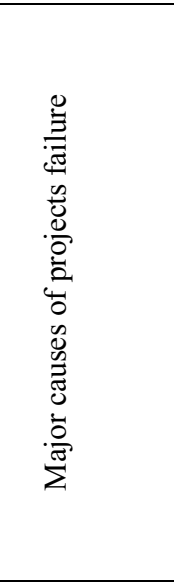 & $\begin{array}{l}\text { 1. No external } \\
\text { consultant to monitor } \\
\text { the work } \\
\text { 2. Red tape (long } \\
\text { time to process } \\
\text { orders) } \\
\text { 3. Poor financial } \\
\text { planning } \\
\text { 4. contract } \\
\text { conditions were } \\
\text { imprecise and } \\
\text { unsteady } \\
\text { 5. lack of } \\
\text { technology }\end{array}$ & $\begin{array}{l}\text { 1. Poor planning } \\
\text { 2. Poor Financial } \\
\text { estimation } \\
\text { 3. Poor communication } \\
\text { among construction } \\
\text { teams } \\
\text { 4. Interference of } \\
\text { government agencies to } \\
\text { interrupt the work } \\
\text { 5. Lack of coordination } \\
\text { from stakeholders } \\
\text { 6. Lack of transparency } \\
\text { among construction } \\
\text { stakeholders }\end{array}$ & $\begin{array}{l}\text { 1. Hiring unqualified } \\
\text { subcontractors } \\
\text { 2. Excessive use of } \\
\text { construction materials } \\
\text { due to the lack of } \\
\text { unified construction } \\
\text { standards and } \\
\text { methods. } \\
\text { 3. Poor planning and } \\
\text { feasibility study } \\
\text { 4. Lack of effective } \\
\text { management skills } \\
\text { 5. Incompetent and } \\
\text { inexperienced } \\
\text { management of } \\
\text { project }\end{array}$ \\
\hline & 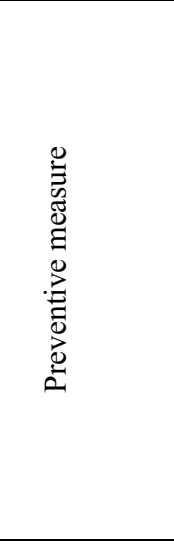 & $\begin{array}{l}\text { 1. Consultant } \\
\text { should have been } \\
\text { selected from } \\
\text { nongovernment } \\
\text { body } \\
\text { 2. Implication of } \\
\text { advanced planning } \\
\text { and scheduling } \\
\text { methods } \\
\text { 3. Associating and } \\
\text { implementing } \\
\text { advanced } \\
\text { technology }\end{array}$ & $\begin{array}{l}\text { 1. Improve } \\
\text { transparency among } \\
\text { construction } \\
\text { stakeholders } \\
\text { 2. Proper planning and } \\
\text { estimation } \\
\text { 3. Developing } \\
\text { guidelines to } \\
\text { administer project } \\
\text { information and } \\
\text { communication } \\
\text { 4. Provide training for } \\
\text { labors before the } \\
\text { commencement of } \\
\text { project }\end{array}$ & $\begin{array}{l}\text { 1. Proper selection of } \\
\text { subcontractors } \\
\text { 2. Proper planning } \\
\text { could have prevented } \\
\text { the failure } \\
\text { 3. Provide skilled } \\
\text { managers to train } \\
\text { subcontractors in } \\
\text { management context } \\
\text { 4. Developing guideline } \\
\text { to constrain the } \\
\text { regulation of accrediting } \\
\text { contactors }\end{array}$ \\
\hline
\end{tabular}




\section{Conclusion}

It can be concluded that, Yemen construction industry faces many challenges and problems which requires more attention from the government to improve its policies and strategies. This cases studies managed to uncover most of failure causative factors are relatively due to the governmental policies and lack of accreditation systems of stakeholders. In Sana'a, international airport project, the dominant factor is due to the diversity of stakeholders of the project that caused lack of communication and understanding amongst the construction practitioners. For Parliament complex most of the problems is due to government bureaucracy while in Sana'a-Sa'dah highway, the main issue was the selection of unqualified subcontractors to take part in the project that causes poor quality control and finally resulted in the failure of the project. Hence, Yemen is in dire need of national system of codes, standards and contractual guidelines. Thus, more studies should to be carried out to explore opportunities for improving Yemen construction industry.

Authors acknowledge the financial support provided by Universiti Tun Hussein Onn Malaysia.

\section{References}

[1] M.E. Abd El-Razek, H.A. Bassioni and A.M. Mobarak, Causes of delay in building construction projects in Egypt, J. Constr. Eng. and Manage., 134(11), 831-841, (2008)

[2] W.E. Alaghbari, R.A. Kadir, M.A. Salim and Ernawati, The significant factors causing delay of building construction projects in Malaysia, Eng., Constr. Architect. Manage., 14(2), 192-206, (2007).

[3] A. Dubois and L. Gadde, The construction industry as a loosely couple system: Implications for productivity and innovation, Constr. Manage. and Econ., 20(7), 621631, (2002)

[4] D.W. Chan and M.M. Kumaraswamy, A comparative study of causes of time overruns in Hong Kong construction projects, Int. J. Project Manage., 15(1), 55-63, (1997).

[5] X. Fei, and T.H. Khan, Identifying Attributes for Expert Construction Project Managers in the Context of China, Int. J. Asian Social Sci., 5(7), 407-418, (2015).

[6] J.J. Chen, The characteristics and current status of China's construction industry, Constr. Manage. Econ., 16(6), 711-719, (1998)

[7] P.F. Kaming, P.O. Olomolaiye, G.D. Holt and F.C. Harris, Factors influencing construction time and cost overruns on high-rise projects in Indonesia, Constr. Manage. Econ., 15(1), 83-94. (1997).

[8] A.H. Memon and I. Abdul Rahman, SEM-PLS Analysis of inhibiting factors of cost performance for large construction projects in Malaysia: Perspective of clients and consultants, The Scientific World J., 165158, (2014)

[9] Ministry of Public works and Highways, Synopsis, Retrieved from: http://www.mpwhye.net/en/website/ministry/detail.php?ID=1454\&lang=en (2016).

[10]B. Sultan, impediments to the construction industry development of Yemen, J. of Sci. Tech., 18, (2013).

[11]B.M. Sultan, The construction industry in Yemen: Towards economic sustainability, $\mathrm{PhD}$ Thesis, Queensland University of Technology, Australia, (2005)

[12]B.M. Sultan and S.L. Kajewski, The Yemen construction industry: Readying the industry for the successful implementation of sustainability, Queensland University of Technology, Australia, (2003)

[13]B. Sultan and W.E. Alaghbari, Incompetent construction technologies and resources in the construction industry of Yemen, KICEM J. Constr. Eng. Project Manage., 19(27), 2233-9582, (2014) 